\title{
Increasing the Ocra's Yield by Organic Fertilizer Applications
}

\author{
Made Sri Yuliartini ${ }^{1}$, Luh Kartini ${ }^{2}$, Kadek Satriawan ${ }^{3}$ \\ \{yuliatinisri@yahoo.co.id ${ }^{1}$ \} \\ Department of Agrotechnology, Faculty of Agriculture, Warmadewa University ${ }^{123}$
}

\begin{abstract}
The purpose of this reseach is to determine the right concentration of liquid organic fertilizer biomi which is combined with the fertillizing frequency on the growth and yield of okra plants. This research was conducte in Sumerta Village, East Denpasar Subdistrict, Denpasar City. This experiment is a factorial experiment using a randomized block design (RBD) consisting of two treatment factors, namely the concentration of biomi liquid organic fertilizer $(\mathrm{K})$ and frequency of application $(\mathrm{F})$. The factor of concentration of liquid organic fertilizer biomi consists of 4 levels: $\mathrm{K}_{0}=0 \mathrm{ml} . \mathrm{l}^{-1}, \mathrm{~K}_{1}=2,5$ ml. $\mathrm{l}^{-1}, \mathrm{~K}_{2}=5 \mathrm{ml} . \mathrm{l}^{-1}$, and $\mathrm{K}_{3}=7,5 \mathrm{ml} . \mathrm{l}^{-1}$. The frequency factor of application consists of 3 levels: $F_{1}=$ fertillizing frequency 2 times, $F_{2}=$ fertillizing frequency 3 times and $F_{3}=$ fertillizing frequency 4 times. Interaction treatment betwen the biomi liquid organic fertilizer consentration and fertillizing frequency as well as single treatment fertillizing frequency had no significant effect on all observed variables while the concentration of liquid organic fertilizer biomi significannly effected to the maximum number of leaves per plant and no significant effect on other variables. The distribution of biomi liquid organic fertillizer at various levels of concentration is not significantly different but the highest fresh weight of fruit per plant was obtained at a concentration of liquid organic fertilizer biomi $5 \mathrm{ml}^{-1}$ which was $300.93 \mathrm{~g}$ which increased by $4,55 \%$ if it is compared with the lowest weight obtained with a concentration of $2,5 \mathrm{ml} . \mathrm{l}^{-1}$, which is $287,83 \mathrm{~g}$. Fertillizing frequency 3 times, can provide the highest fresh fruit weight per plant, which was $299,14 \mathrm{~g}$ which has increased by $1,99 \%$ and $3,69 \%$ if it is compared to the fertillizing frequency 2 times, which is $293,28 \mathrm{~g}$ and the lowest fertillizing frequency 4 times is $288,48 \mathrm{~g}$.
\end{abstract}

Keywords: biomi liquid organic fertilizer, frequency of fertilizer application and okra plants.

\section{Introduction}

Okra plants in Indonesia have been planted since 1877 especially in West Kalimantan. This plant has been cultivated for along time by Chinese farmers as vegetables, which are especially preferred for daily family needs, supermarkets, restaurants, restaurants and hotels. Okra (Abelmoschus esculentus) is a vegetable plant that grows in tropical and sub-tropical regions. In Bali this plant is not well known both in terms of cultivation and utilization. It is only found in large supermarkets. In some place's okra is known by a different name, some people call it okura, bendi beans or lady finger. This plant is very popular in Asian countries such as Japan, Malaysia, China and India [1]. 
Okra can be used as vegetable and also as medicine. The part that can be used as vegetable and medicine is the fruit (young fruit) or "baby" okra. As medicine, okra fruit can provide positive benefits for the body in maintaining health. The vegetable of young fruit okra can be consumed by boiling, sautéing, or slicing and being eaten directly. The fruit contains a lot of mucus. So, it is well made into soup. Young okra fruit contains $85.70 \%$ moisture content; protein $8.30 \% ; 2.05 \%$ fat; $1.4 \%$ carbohydrates and $38.9 \%$ calories per $100 \mathrm{~g}$ [2]. Young fruits consist of a long chain of molecules with a molecular weight of about 170,000 consisting of units of sugar and amino acids. The main components are galactose (25\%), rhamnose $(22 \%)$, galacturonic acid $(27 \%)$ and amino acids $(11 \%)$. This mucus is very easy to dissolve in water. The solution in water has an intrinsic viscosity value of around 30\% [3]. Okra seeds contain about $20 \%$ protein similar to the amino acid composition of soy protein and $20 \%$ oil (similar in composition to cottonseed fatty acids). Okra flowers can be very attractive and are sometimes used in living room decorations [4]. Okra plants start flowering at the age of 50 days after planting. Okra fruit can be harvested young size $6.5-9 \mathrm{~cm}$ and a little old with a size of 12-17 cm. Young okra fruit or better known as "baby" okra can be eaten directly using vegetables.

In the vegetable development program, it is required to increase efficiency of production costs and increase added value. One alternative for the cultivation of vegetable cultivation is by reducing production costs by using and applying the right fertilizer and according to the optimal needs of the plant [2]. Organic fertilizers are fertilizers that play a role in increasing biological, chemical, and physical activities of the soil so that the soil becomes fertile and good for plant growth [5]. One form of organic fertilizer is Liquid organic fertilizer (POC), which is organic fertilizer in liquid preparations.

Liquid organic fertilizers, namely organic fertilizers in liquid preparations, contain nutrients in the form of very fine solutions so that they are easily absorbed by plants, even by the leaves or stems. This fertilizer can be applied by splashing or by spraying on the leaves or on the stem of the plant. Sources of raw materials for organic fertilizers are available everywhere with abundant quantities which are all in the form of waste, both household waste, restaurants, agricultural markets, livestock, and other types of organic waste [6]. Liquid organic fertilizer can provide added value to plants during the growth and development of plants, besides this fertilizer is also useful in improving soil because it contains microorganisms that can reduce disease attacks on fertilized plants. Fertilizers used are biomi liquid organic fertilizer which is a fertilizer produced by solid waste and cow's liquid waste with additional starters developed by the Animal Husbandry Study Program of the Faculty of Agriculture, Warmadewa University in collaboration with livestock farmer groups. Liquid organic fertilizer biomi has complete nutrients that can contribute to plant growth and development. In vegetable plants the concentration of recommendations for vegetable plants is $2-3 \mathrm{cc} /$ liter of water.

Availability of nutrients in the soil is influenced by many factors. The right concentration factor for fertilization will affect the yield of a plant. Plants can make maximum use of nutrients from fertilizers through minimization of washing and evaporation. One way to avoid evaporation and washing of fertilizers is to do repeated fertilization, or in other words regulate the frequency of fertilization in plant. In addition to providing fertilizer concentration, other ways to maintain nutrient availability in the soil can also be done with the frequency of fertilizer application, how to administer fertilizer, and the form of fertilizer that is used appropriately. The success in fertilizing is also determined by the time factor of fertilization. Fertilization time must be right, for example, fertilizers that are too early will make fertilizer 
quickly disappear so that it is not absorbed by plants, so fertilizer is given when plants need nutrients and are available to plants [7].

\section{Methodology}

The study was conducted in paddy fields in Sumerta Village, East Denpasar District, Denpasar City, with a height of 15 meters above sea level and an average temperature of $25^{\circ} \mathrm{C}$ to $30^{\circ} \mathrm{C}$. The time of the study began in April - July 2018, followed by the oven and tabulation of data and analysis until September 2018.

This experiment is a factorial experiment using a randomized block design (RBD) consisting of two treatment factors, namely the concentration of biomi liquid organic fertilizer $(\mathrm{K})$ and frequency of application $(\mathrm{F})$. The factor of concentration of liquid organic fertilizer biomi consists of 4 levels: $\mathrm{K} 0=0 \mathrm{ml} .1-1, \mathrm{~K} 1=2,5 \mathrm{ml} .1-1, \mathrm{~K} 2=5 \mathrm{ml} .1-1$, and $\mathrm{K} 3=7,5 \mathrm{ml} .1-1$. The frequency factor of application consists of 3 levels: F1 = fertillizing frequency 2 times, F2 $=$ fertillizing frequency 3 times and F3 = fertillizing frequency 4 times. The combination treatment was repeated 3 times, so 36 trial plots were needed.

The research included land preparation, the land was tractored three times, then cleaned and leveled, made a plot of size $2 \times 2 \mathrm{~m}$ with a height of $20 \mathrm{~cm}$ of mounds, distance between plots $30 \mathrm{~cm}$ and between replications $50 \mathrm{~cm}$; seed seedlings, before the seeds are soaked for 3 hours, then seeded at the nursery, next planting is done in the afternoon after the seeds have boiled 14 days after the seedling with a spacing of $50 \times 50 \mathrm{~cm}$. Plant maintenance includes fertilizing/irrigating, fertilizers, weeding and controlling pests also the diseases.

Giving treatment is the application of biomi liquid organic fertilizer done with the dilution method is in accordance with the level of treatment, i.e. the level without fertilizer treatment, $2.5 \mathrm{ml}, 5 \mathrm{ml}$, and $7.5 \mathrm{ml}$ each diluted / diluted into water until it becomes 1 liter of dissolved solution or equal to $1,000 \mathrm{ml}$ dissolved solution. The frequency of application is given according to the treatment, namely the fertilizing frequency twice (age 10 days and 20 days), the fertilizing frequency 3 times (age 10 days, 20 days, and 30 days), and fertilizing frequency 4 times (age 10 days, 20 days, 30 days, and 40 days). The dose given is 1,000 ml.1 in one phase of life of the okra plant because liquid organic fertilizer biomi is still new and has never been used in previous studies.

In general, okra plants are harvested at the age of 45 days after planting, at when the fruit is young. Criteria for okra fruit harvested from the baby (baby okra) size $6.5-9 \mathrm{~cm}$, the fruit harvested is smooth green. Harvesting is done by cutting the fruit stalks.

The research instruments will be carried out on variables, namely plant height, number of leaves, number of fruits per plant, fresh and dry weight of fruit oven per plant, fresh and dry weight of Stover oven per plant.

The research data were analyzed statistically using diversity analysis to determine the effect of treatment on observed variables. Whereas, to find out the real difference between treatments used the LSD test with a level of 5\%. To find out the closeness of the relationship between variables observed correlation analysis was carried out.

\section{Result and Discussion}

From the results of statistical analysis of all observed variables and the results of the significance of biomi organic liquid fertilizer concentration $(\mathrm{K})$ and fertillizing frequency (F) and their interaction $(\mathrm{KxF})$ on growth and yield of okra plants are presented in Table 1. 
Table 1. Significance biomi organic liquid fertilizer concentration $(K)$ and ferillizing frequency $(F)$ and its interaction $(\mathrm{KxF})$ for all observed variables.

\begin{tabular}{lccc}
\hline No Variable & \multicolumn{3}{c}{ Treatment } \\
\cline { 2 - 4 } & $\begin{array}{c}\text { Biomi Consentration } \\
(\mathrm{K})\end{array}$ & $\begin{array}{c}\text { Frequency } \\
(\mathrm{F})\end{array}$ & $\begin{array}{c}\text { Interaction } \\
(\mathrm{KxF})\end{array}$ \\
\hline 1 Maximum plant height $(\mathrm{cm})$ & $\mathrm{ns}$ & $\mathrm{ns}$ & $\mathrm{ns}$ \\
2 Maximum number of leaves per plant (sheet) & $*$ & $\mathrm{~ns}$ & $\mathrm{~ns}$ \\
3 Number of fruiets per clump (fruit) & $\mathrm{ns}$ & $\mathrm{ns}$ & $\mathrm{ns}$ \\
4 Fresh weight of fruit per plant $(\mathrm{g})$ & $\mathrm{ns}$ & $\mathrm{ns}$ & $\mathrm{ns}$ \\
5 Dry weight of fruit oven per palnt $(\mathrm{g})$ & $\mathrm{ns}$ & $\mathrm{ns}$ & $\mathrm{ns}$ \\
6 Fresh weight of stover per plant $(\mathrm{g})$ & $\mathrm{ns}$ & $\mathrm{ns}$ & $\mathrm{ns}$ \\
7 Dry weight oven stover per plant $(\mathrm{g})$ & $\mathrm{ns}$ & & \\
\hline
\end{tabular}

Description: $\mathrm{ns}=$ Not significant effect $(\mathrm{P} \geq 0.05)$

$$
\begin{aligned}
* & =\text { Significant influence }(\mathrm{P}<0.05) \\
* * & =\text { Very significant effect }(\mathrm{P}<0.01)
\end{aligned}
$$

The biomi organic liquid fertilizer conentration has a significant effect $(\mathrm{P}<0.05)$ on the maximum number of leaves per plant and has no significant effect $(\mathrm{P} \geq 0.05)$ on other variables. The treatment of fertillizing frequency $(\mathrm{F})$ and the interaction treanment betwen the biomi liquid organic fertilizer consentration and fertillizing frequency $(\mathrm{KxF})$ had no significant effect $(\mathrm{P} \geq 0.05)$ on all observed variables (Table 1$)$

1. Maximum plant height $(\mathrm{cm})$

The increasing concentration of Biomi liquid organic fertilizer causes the average maximum plant height which tends to increase The treatment fertillizing frequency 3 times (F2) gives the highest maximum plant height with a value of $109.88 \mathrm{~cm}$ followed by the fertilllizing frequency of 4 times (F3) which is $108.68 \mathrm{~cm}$ and the fertillizing frequency 2 times (F1) which is $105.21 \mathrm{~cm}$ (Table 2).

2. Maximum number of leaves (sheet)

The highest average number of leaves per plant was obtained at the biomi liquid organic fertilizer concentration $5 \mathrm{ml} .1-1$ (K2) 37.17 strands and the lowest was obtained at the biomi liquid organic fertilizer 0 ml.1-1 (K0) 32.58 strands. The treatment frequency 2 times (F1) gives the highest maximum number of leaves per plant, which is 35.38 strands, followed by the fertillizing frequency 3 times (F2), which is 34.54 strands and fertillizing frequency 4 times (F3), 33.17 sheet (Table 2).

3. Number of fruits (fruit)

The highest average number of fruits per plant tended to be obtained at the biomi liquid organic fertilizer concentration $5 \mathrm{ml} .1-1$ (K2) which was 24.08 fruits and the lowest was obtained at $2.5 \mathrm{ml} .1-1$ (K1) treatment which was 22.83 fruit. The fertillizing frequency 2 times (F1) and the fertillizing frequency 3 times (F2) gives an average number of fruits per plant that is 23,42 different fruits which are not significant with the fertillizing frequency 4 times (F3) which is 23.15 pieces (Table 2).

4. Fresh Weight of Fruit per plant (g)

The highest average weight of fruit per plant was obtained at a concentration of $5 \mathrm{ml} .1-1$ (K2) with a value of $300.93 \mathrm{~g}$ followed by a treatment of $7.5 \mathrm{ml} .1-1$ (K3) which was 293.14 $\mathrm{g}$, treatment without concentration (K0) is $292.64 \mathrm{~g}$, and that obtained the lowest average fresh fruit weight per plant in the $2.5 \mathrm{ml} .1-1$ (K1) treatment which was $287.83 \mathrm{~g}$. The fertillizing frequency 3 times (F2) gives the highest average fresh fruit weight, which is $299.14 \mathrm{~g}$, followed by the fertillizing frequency 2 time (F1) which is $293.28 \mathrm{~g}$ and the fertillizing frequency 4 times (F3) which is $288.48 \mathrm{~g}$ (Table 2). 
5. Fresh Weight of Stover per plant (g)

The highest average weight of stover per plant tends to be obtained at the biomi liquid organic fertilizer concentration $5 \mathrm{ml} .1-1$ (K2) which is $1696.26 \mathrm{~g}$ and the lowest biomi liquid organic fertilizer concentration 0 ml.l-1 (K0) is $1566,67 \mathrm{~g}$. The fertillizing frequency 3 times (F2) gives the highest average weight of stover per plant that is 1694.58 $\mathrm{g}$ followed by fertillizing frequency 2 times (F1), namely $1640.53 \mathrm{~g}$ and the lowest is obtained at a frequency 4 times (F3), 1579, $38 \mathrm{~g}$ (Table 2).

6. Dry Weight of Fruit Oven per plant (g)

The highest average oven dry weight per plant tends to be obtained at the concentration of liquid organic fertilizer biomi 5 ml.1-1 (K2) which is $10.17 \mathrm{~g}$ and the lowest concentration of liquid organic fertilizer is obtained biomi $2.5 \mathrm{ml} .1-1$ (K1) which is $8.43 \mathrm{~g}$. The fertillizing frequency 2 time (F1) gave the highest average oven dry weight per plant ie $10.33 \mathrm{~g}$, followed by the treatment frequency 3 times (F2) which is $9.20 \mathrm{~g}$ and the lowest treatment was given 4 times (F3), namely $8.60 \mathrm{~g}$ (Table 2).

7. Dry Weight Oven Stover per plant (g)

The highest average dry weight of oven oven per plant was obtained at the biomi liquid organic fertilizer concentration $7.5 \mathrm{ml} .1-1$ (K2) with a value of $323.25 \mathrm{~g}$ and the lowest biomi liquid organic fertilizer $0 \mathrm{ml} .1-1$ (K0) which is $257.55 \mathrm{~g}$. The fertillizing frequency 3 times (F2) gave the highest average dry weight of oven per plant ie $293.97 \mathrm{~g}$ followed by the treatment frequency 4 times (F3) which was $285.43 \mathrm{~g}$ and treatment frequency 2 times (F1), 281 , $56 \mathrm{~g}$ (Table 2).

Interaction treatment between the biomi liquid organic fertilizer concentration and fertillizing frequency had no significant effect on all observed variables.

The biomi liquid organic fertilizer concentration has a significant effect on the maximum number of leaves per plant. The maximum number of leaves per plant was obtained at the biomi liquid organic fertilizer concentration 5 ml.1-1 which was 37.17 sheet which increased by $14.09 \%$ compared to the biomi liquid organic fertilizer concentration 0 ml.l-1 which is 32.58 sheet, maximum leaf per plant at biomi liquid organic fertilizer concentration 5 ml.l-1 followed by an increase in the number of fruits $(\mathrm{r}=0.94 * *)$, fresh weight of fruit $(\mathrm{r}=$ $0.89 * *)$, dry weight of fruit oven $(0,88 * *)$, fresh berangkasan weight $(\mathrm{r}=0.75 * *)$ and dry oven weight $(0.66 *$ ) (Table 3 ). Biomi liquid organic fertilizer contains macro and micro nutrients and organic materials needed by plants for their growth and development. Liquid organic fertilizer has benefits that can encourage and increase the formation of leaf chlorophyll so that it can improve plant photosynthesis ability, increase flower formation, and fruiting, reduce the fall of leaves, flowers, and ovaries [8].

The application of biomi liquid organic fertilizer in sharing the concentration level has not given a real effect on the results of okra plants, this is due to the level of concentration given has not been able to provide higher yields than without the provision of liquid organic fertilizer biomi this is due to nutrients contained in the soil that is, moderate $\mathrm{N}$, high $\mathrm{P}$ and $\mathrm{K}$ are sufficient for growth and yield of okra plants so that the administration of liquid organic fertilizer biomi is more on improving soil physical properties, soil chemistry and biology. Organic fertilizers can improve soil physical properties because more stable aggregate formation, improved soil aeration and draenase, can reduce erosion because infiltration of rainwater is good and the ability of soil to hold water increases. Organic fertilizers can improve soil chemical properties because they can increase soil nutrients both macro and micro, increase the efficiency of nutrient extraction, increase cation exchange capacity, and can neutralize the toxic properties of $\mathrm{Al}$ and $\mathrm{Fe}$. Organic fertilizers can also improve the 
biological properties of soil because organic fertilizer is an energy source for microorganisms / soil microbes that are capable of releasing nutrients for plants [5].

Table 2. The average value of all variables observed in the treatment of liquid organic fertilizer concentration biomi $(\mathrm{K})$ and frequency of administration $(\mathrm{F})$

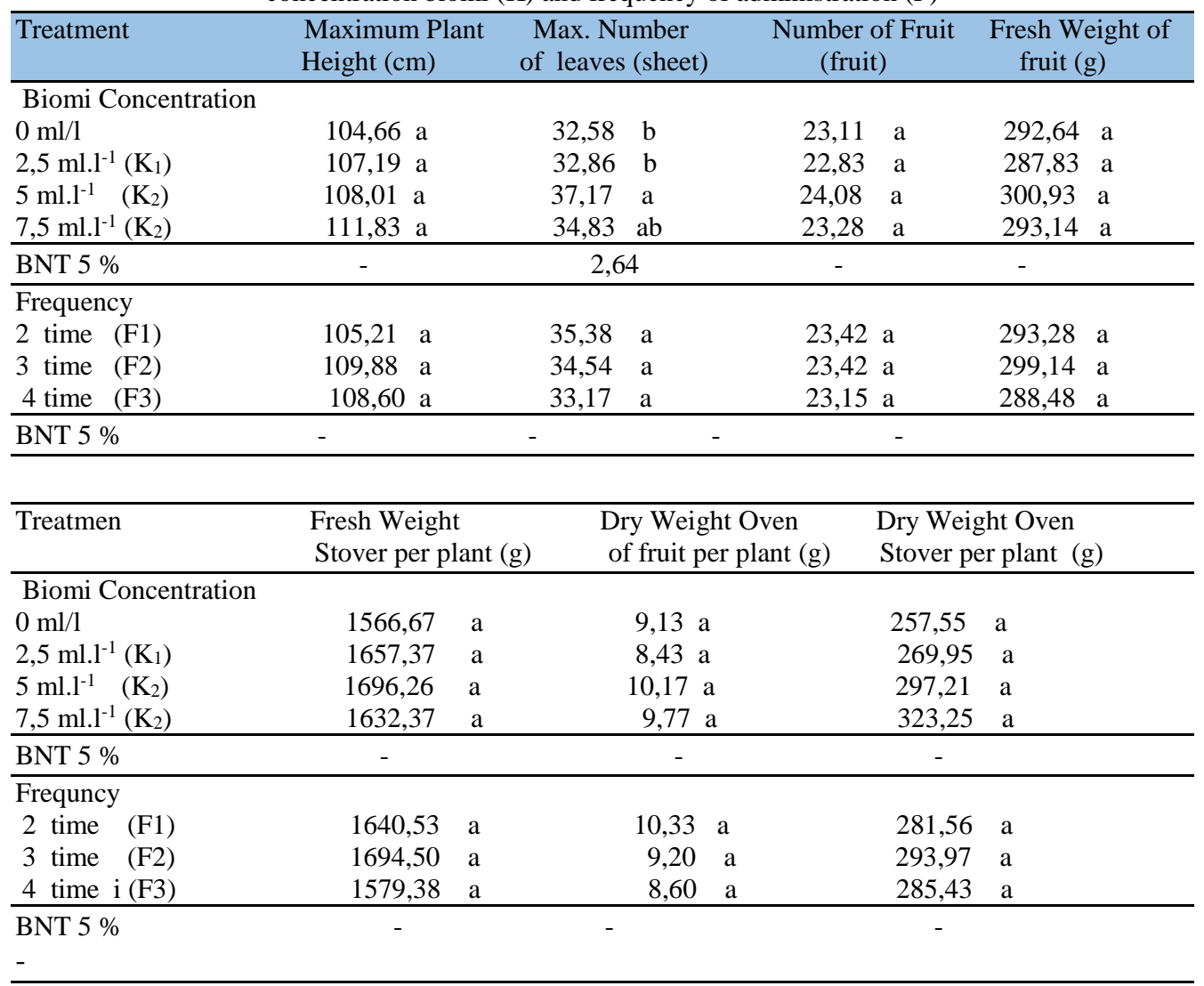

Fresh weight and dry weight oven tend to be the highest obtained at biomi liquid organic fertilizer concentration $5 \mathrm{ml} .1-1$ which is $300.93 \mathrm{~g}$ and $10.17 \mathrm{~g}$, increasing by $4.55 \%$ and $20.64 \%$ when compared with biomi liquid organic fertilizer concentration $2.5 \mathrm{ml} .1-1$ which is $287.83 \mathrm{~g}$ and $8.43 \mathrm{~g}$. The increase in fresh weight and dry weight of fruit oven per plant at biomi liquid organic fertilizer concentration $5 \mathrm{ml} .1-1$ was supported by the variable maximum number of leaves per plant $(\mathrm{r}=0.89 * *)$, and $(\mathrm{r}=0.88 * *)$ and the number of fruits per plant $(\mathrm{r}$ $\left.=0.99^{* *}\right)$ and $\left(\mathrm{r}=0.90^{* *}\right)$ (Table 3$)$. The highest number of fruits per plant tends to be obtained at the concentration of liquid organic fertilizer biomi $5 \mathrm{ml} .1-1$ which is 24.08 fruits which increases by $5.47 \%$ compared to biomi liquid organic fertilizer concentration $2.5 \mathrm{ml} .1-1$ which is 22.83 fruit. 
Table 3. Value of correlation coefficient (r) between variables due to the influence of biomi liquid organic fertilizer concentration

\begin{tabular}{|c|c|c|c|c|c|c|c|}
\hline & 1 & 2 & 3 & 4 & 5 & 6 & 7 \\
\hline 1 & 1 & & & & & & \\
\hline 2 & $0,48^{\mathrm{ns}}$ & 1 & & & & & \\
\hline 3 & $0,20^{\mathrm{ns}}$ & $0,94 * *$ & $-0,42^{\mathrm{ns}}$ & & & & \\
\hline 4 & $0,13^{\mathrm{ns}}$ & $0,89 * *$ & $-0,49^{\text {ns }}$ & 1 & & & \\
\hline 5 & $0,46^{\mathrm{ns}}$ & $0,88 * *$ & $-0,77 * *$ & $0,91 * *$ & 1 & & \\
\hline 6 & $0,42^{\text {ns }}$ & $0,75^{* *}$ & $0,21^{\mathrm{ns}}$ & $0,44^{\mathrm{ns}}$ & $0,35^{\mathrm{ns}}$ & 1 & \\
\hline 7 & $0,96^{* *}$ & $0,66^{*}$ & $-0,68 *$ & $0,39^{\text {ns }}$ & $0,68 *$ & $0,45^{\mathrm{ns}}$ & 1 \\
\hline \multicolumn{5}{|c|}{$\mathrm{r}(0,05 ; 10 ; 1)=0,576$} & \multicolumn{3}{|c|}{$\mathrm{r}(0,01 ; 10 ; 1)=0,708$} \\
\hline & $\begin{array}{l}\text { ximum } p \\
\text { ximum r } \\
\text { nber of } \\
\text { h weigh } \\
\text { n dry fru } \\
\text { oven we } \\
\text { eal influ } \\
\text { ery sign } \\
\text { t signif }\end{array}$ & $\begin{array}{l}\text { height }( \\
\text { er of lea } \\
\text { per plan } \\
\text { fruit per } \\
\text { eight per } \\
\text { per plan } \\
\text { (P<0.05 } \\
\text { nt effect } \\
\text { effect ( }\end{array}$ & $\begin{array}{l}\text { per plan } \\
\text { fruit) } \\
\text { int }(\mathrm{g}) \\
\text { ant }(\mathrm{g}) 6= \\
\text { ) } \\
<0.01) \\
.05)\end{array}$ & $\begin{array}{l}\text { trands) } \\
\text { reight of }\end{array}$ & esh fruit & plant & \\
\hline
\end{tabular}

The fertillizing frequency used, intends to divide the volume of gifts from each biomi liquid organic fertilizer concentration which has been dissolved into one liter of dissolved solution given one lifetime of okra plants so that the availability of nutrients from liquid organic fertilizer biomi for vegetative phase and generative phase of plants okra becomes more efficient and also reduces the evaporation of fertilizers by the environment. Fertillizing frequency has not given a significant effect on the growth and yield of okra plants but the fertillizing frequency 3 times tends to give growth and yield of okra plants seen from plant height, number of fruits, fresh weight of fruit, fresh weight and dry weight of crusty oven. Fertillizing frequency 3 times tends to give the highest fresh fruit per plant, which is $299.14 \mathrm{~g}$, increasing by $1.99 \%$ and $3.69 \%$ when compared with fertillizing frequency 2 time, $293.28 \mathrm{~g}$ and the lowest fertillizing frequency 4 times, $288,48 \mathrm{~g}$.

\section{Conclusion and Recommendations}

\subsection{Conclusion}

Interaction treanment betwen the biomi liquid organic fertilizer consentration and fertillizing frequency as well as single treatment fertillizing frequency had no significant effect on all observed variables while the concentration of liquid organic fertilizer biomi significannly effected to the maximum number of leaves per plant and no significant effect on other variables.

The distribution of biomi liquid organic fertillizer at various levels of concentration is not significantly different but the highest fresh weight of fruit per plant was obtained at a 
concentration of liquid organic fertilizer biomi $5 \mathrm{ml}^{-1^{-1}}$ which was $300.93 \mathrm{~g}$ which increased by $4,55 \%$ if it is compared with the lowest weight obtained with a concentration of $2,5 \mathrm{ml} . \mathrm{1}^{-1}$, which is $287,83 \mathrm{~g}$.

Fertillizing frequency 3 times, can provide the highest fresh fruit weight per plant, which was $299,14 \mathrm{~g}$ which has increased by $1,99 \%$ and 3,69 \% if it is compared to the fertillizing frequency 2 times, which is $293,28 \mathrm{~g}$ and the lowest fertillizing frequency 4 times is $288,48 \mathrm{~g}$.

\subsection{Suggestion}

1) Further research is needed regarding the concentration of liquid organic fertilizer biomi and the fertillizing frequency that is more improved and varies in different places with the condition of the previous land in order to have a significant influence on the growth and yield of young fruits of okra plants.

2) Research needs to be done with other cultivation technology inputs so that the cultivation and utilization of okra plants is better known.

\section{References}

[1] Frank, S.: Biology Of Okra.: Department of Biotechnology. India (2009)

[2] Nadira, S., Hatidjah, B., \& Nuraeni.: Pertumbuhan dan Hasil Tanaman Okra (Abelmoschus Esculantus) pada Pelakuan Pupuk Dekaform dan Defoliasi. Agrisains. Vol. 10(1) (2009)

[3] Benchasri, S.: Okra (Abelmoschus esculentus (L.) Moench) as a valuable vegetable of the world. Ratarstvo i povrtarstvo. Vol. 49(1). pp. 105-112 (2012)

[4] Iyagba A.G, Onuegbu, B.A \& IBE, A.E.: Growth and Yield Response of Okra (Abelmoschus esculentus (L.) Moench) Varieties to Weed Interference in South-Eastern Nigeria. Global Journal of Science Frontier Research Agriculture and Veterinary Sciences. Vol. 12(7) (2012)

[5] Indriani, Y.H.: Membuat Kompos Secara Kilat. Penebar Swadaya, Jakarta (2004)

[6] Nasaruddin., \& Rosmawati.: Pengaruh Pupuk Organik Cair (POC) Hasil Fermentasi Daun Gamal, Batang Pisang dan Sabut Kelapa terhadap Pertumbuhan Bibit Kakao. Jurnal Agrisistem, Vol. 7(1). pp. 29-37 (2011)

[7] Damanik, M. M. B., \& Bachtiar, E. H. Fauzi., Sarifuddin, Hamidah H. Kesuburan Tanah dan Pemupukan. USU Press, Medan (2011)

[8] Huda, M.K.: Pembuatan Pupuk Oranik Cair dari Urin Sapi dengan Aditif Tetes Tebu (Molase) Metode Fermentasi. Skripsi Program Studi Kimia. Universitas Negeri Semarang. (2013) 